BIOTROPIA No. 6, 1992/1993: 66-70

\title{
THE ADSORPTION OF IMAZAPYR BY THREE SOIL TYPES IN INDONESIA
}

\author{
S. TJIROSEMITO \\ SEAMEO BIOTROP, P.O. Box 116, Bogor, Indonesia \\ S. MATSUNAKA and M. NAKATA \\ Department of Biotechnology, Faculty of Engineering, \\ Kansai University, Yamate-cho, Suita, Osaka 564, Japan \\ and Lab. Pesticide Science, Faculty of Agriculture, Kobe University, \\ Rokkodaicho, Nadaka, Kobe 657, Japan, respectively
}

\begin{abstract}
The adsorption of imazapyr in three Indonesian soil types was investigated with labelled ${ }^{14} \mathrm{C}$-imazapyr using Freundlich adsorption isotherm. The availability of adsorbed imazapyr to plants as affected by washing and liming was assayed using root elongation of rice seedlings.

Red-Yellow Podsolic soil adsorbed imazapyr more than Andosol and sandy soil of Laladon. The adsorption was greater at lower $\mathrm{pH}$. Washing seemed to reduce the concentration of imazapyr as shown by the increasing length of rice roots. On the other hand liming facilitated higher concentrations of imazapyr in the solution as shown by the reduction of rice root length.

The practical implication is discussed.
\end{abstract}

\section{INTRODUCTION}

Upland rice established in pot experiment by zero tillage technique on alang-alang sprayed with imazapyr at $1.5 \mathrm{~kg}$ a.i./ha died immediately after germination (Tjitrosemito and Purwanto 1991). However, imazapyr applied at $2.0 \mathrm{~kg}$ a.i./ha to soybean, planted using zero tillage technique in the field during the wet season, did not show any phytotoxic effect (Tjitrosemito and Suwinarno 1988). To understand its fate in soil, imazapyr adsorption in various soils and the effect of liming and washing were investigated.

\section{MATERIALS AND METHODS}

The experiment was carried out at the Laboratory of Pesticide Science, Faculty of Agriculture, Kobe University, Japan. Three soil types, i.e. Red-Yellow Podsolic soil (RYP), Andosol and sandy soil of Laladon were air dried, and sieved through a $1 \mathrm{~mm}$ sieve. The $\mathrm{pH}$ was measured in a 1:1 (w/v) soil: deionized water/slurry 
using pH meter (model COM-10, DKK Denki Kagaku Keiki Co. Ltd.). The pH values were 3.75; 4.83 and 5.40 for RYP, Andosol and sandy soil of Laladon, respectively.

\section{Adsorption}

Commercially formulated imazapyr (Assault) was combined with ${ }^{14} \mathrm{C}$-ring labelled imazapyr (specific activity: $43.916 \mu \mathrm{Ci} / \mathrm{mg}$ ) to obtain initial concentration of 5, 25, 45 and $65 \mu \mathrm{M}$. Five grams of air dried soils (sieved through $1 \mathrm{~mm}$ ) and $10 \mathrm{ml}$ of herbicide solution were placed in $30 \mathrm{ml}$ vial. The samples were equilibrated by shaking on a wrist action shaker for 24 hours at room temperature. The mixtures were transferred to centrifuge tubes and spun at $15000 \mathrm{x}$ rpm for 30 minutes. A 2-ml aliquot was removed from each tube and placed in $20 \mathrm{ml}$ of scintillation cocktail and the ${ }^{14} \mathrm{C}$-activity was determined by scintillation spectrophotometry. Adsorption isotherms were constructed using best-fit regression equations. Freundlich constant $\mathrm{K}_{\mathrm{f}}$ and $1 / \mathrm{n}$ were calculated from the equation:

$$
\log (\mathrm{x} / \mathrm{m})=\log \mathrm{K}_{\mathrm{f}}+(1 / \mathrm{n}) \log \mathrm{C}
$$

where, $\mathrm{x} / \mathrm{m}=$ the amount of herbicide adsorbed $(\mu$ mole $/ \mathrm{kg})$

$\mathrm{C}=$ herbicide concentration $(\mu \mathrm{mole} / \mathrm{I})$ in solution after equilibrium

$\mathrm{Kf}=$ Freundlich constant, an indicator of relative adsorption of herbicide at unit concentration (i.e. $\mathrm{C}=1 \mu$ mole/1)

$(1 / n)=$ indication relative linearity between adsorption and concentration.

\section{The Phytotoxicity of Imazapyr}

A rice bioassay was conducted by placing $5 \mathrm{~g}$ of air dried soil into 30-ml tubes containing commercially formulated imazapyr. The mixtures were allowed to equilibrate for $24 \mathrm{hr}$ by shaking in a shaker. After equilibration, washing treatment was done by replacing the solution with deionized water and later on, 10 pre-soaked rice seeds were put in each tube.

After 3 days, the rice root length was measured and analysed statistically.

The treatments consisting of soil (Red-Yellow Podsolic Soil, Andosol and Laladon sandy soil), imazapyr (0, 0.1 and $0.2 \mathrm{ppm}$ ), liming (addition of $\mathrm{CaCO}_{3}$ at $0.1 \%$ $(-/+))$ and washing $(-/+)$ were combined factorially and randomized completely. 


\section{RESULTS AND DISCUSSION}

The relationship between the amount of adsorbed imazapyr and its equilibrium concentration in 3 types of soil is presented in Figure 1.

Red-Yellow Podsolic soil, the highly weathered soil with low $\mathrm{pH}$ adsorbed more imazapyr than Andosol or Sandy soil of Laladon. The addition of $\mathrm{CaCO}_{3}$ somehow reduced the adsorption considerably.

The calculation of Freundlich equation showed the characteristic of adsorption (Table 1).

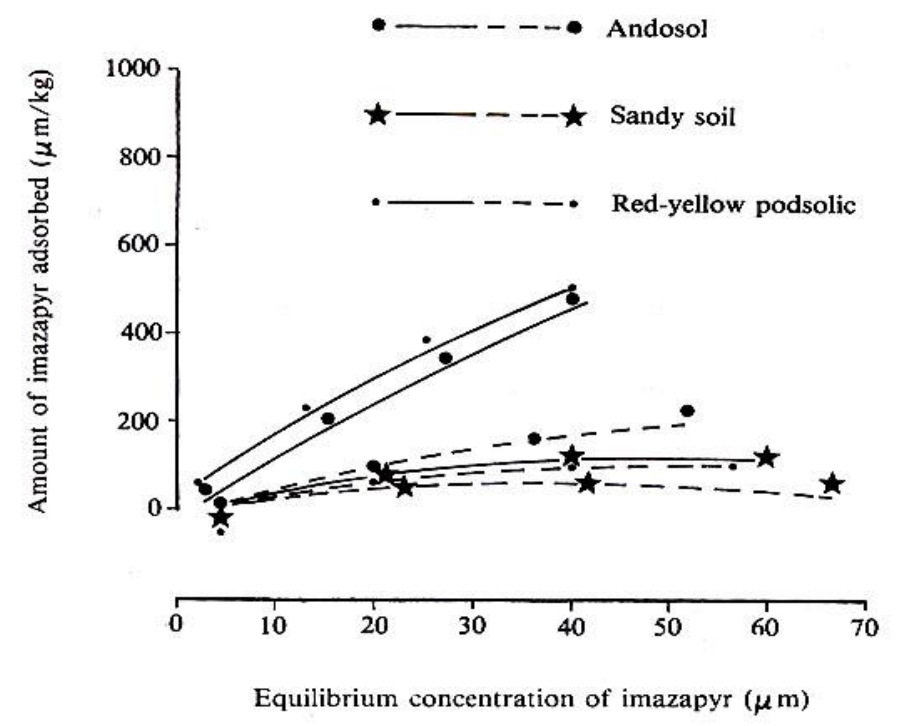

Figure 1 . The relationship between the amount of imazapyr adsorbed and its equilibrium concentration

From Table 1 the value of $(1 / \mathrm{n})$ ranged from 0.67 to 1.10 indicating a nonlinear relationship between the amount adsorbed and the equilibrium concentration. Freundlich constant of RYP showed the highest value $(246.0 \mu \mathrm{M} / \mathrm{kg})$ indicating that it has the highest affinity for imazapyr. In RYP soil alang-alang is usually found abundantly. 
The adsorption of imazapyr by three soil types - S. Tjitrosemito, S. Matsunaka and M. Nakata

Table 1. Relative adsorption of imazapyr $(\mathrm{Kf})$ and coefficient of regression $\left(\mathrm{r}^{2}\right)$ on soils.

\begin{tabular}{llccc}
\hline \hline Soil & Lime & $\mathrm{K}_{\mathrm{f}}(\mu$ mole/ $/ \mathrm{kg})$ & $1 / \mathrm{n}$ & $\mathrm{r}^{2}$ \\
\hline Red-Yellow & & & & \\
Podsolic Soil & 246.0 & & 0.84 & 0.99 \\
(pH 3.75) & + & 98.0 & 0.67 & 0.99 \\
Andosol & 120.5 & & 0.98 & 0.99 \\
(pH 4.83) & + & 34.7 & 1.05 & 0.98 \\
Sandy soil of Laladon & 17.4 & & 1.10 & 0.92 \\
(pH 5.40) & + & 15.9 & 0.95 & 0.77 \\
\hline
\end{tabular}

When the values of $\mathrm{K}_{\mathrm{f}}$ and $\mathrm{pH}$ were examined, there was a linear relationship, i.e. $\mathrm{Y}=756.22-134.4 \mathrm{x}\left(\mathrm{r}^{2}=0.98\right)$, where $\mathrm{Y}=\mathrm{K}_{\mathrm{f}}$ and $\mathrm{x}=\mathrm{pH}$ value. The adsorption of imazapyr increased with the decrease in soil $\mathrm{pH}$, similar results were reported by Stougaard et al. (1990), Wehtje et al. (1987) and Arnold (1981).

When the soil was limed, soil pH increased and presumably more imazapyr molecules stayed in the solution.

\section{Phytotoxicity of imazapyr}

Rice (Norin No. 8) as a test plant in this bioassay showed a severe root length reduction when exposed to the soil treated with 0.1 or 0.2 ppm of imazapyr solution (Table 2 a).

Table 2. Root length (mm) of rice as affected by imazapyr and washing, liming, and soil types.

\begin{tabular}{|c|c|c|c|c|}
\hline \multirow[t]{2}{*}{ Treatments } & \multicolumn{4}{|c|}{ Imazapyr (ppm) } \\
\hline & $\overline{0}$ & 0.1 & 0.2 & \\
\hline \multicolumn{5}{|l|}{ a Washing } \\
\hline No washing & 32.7 & 18.3 & 14.7 & \multirow[b]{2}{*}{$\operatorname{LSD}(5 \%): 5.3$} \\
\hline With washing & 35.1 & 28.2 & 20.5 & \\
\hline \multicolumn{5}{|l|}{ b Liming } \\
\hline No liming & 35.1 & 27.2 & 18.7 & \multirow[b]{2}{*}{$\operatorname{LSD}(5 \%): 6.1$} \\
\hline With liming & 31.2 & 19.4 & 15.6 & \\
\hline \multicolumn{5}{|l|}{ c Soil } \\
\hline Red- Yellow Podsolic & 31.8 & 28.7 & 20.7 & \multirow[b]{3}{*}{$\operatorname{LSD}(5 \%): 5.3$} \\
\hline Andosol & 31.0 & 20.3 & 16.8 & \\
\hline Sandy soil of Laladon & 23.8 & 20.8 & 15.3 & \\
\hline
\end{tabular}


The reduction of root length was modified by washing. Root length was increased from $18.3 \mathrm{~mm}$ to $28.2 \mathrm{~mm}$ and from $14.7 \mathrm{~mm}$ to $20.5 \mathrm{~mm}$ for $0.1 \mathrm{ppm}$ and 0.2 ppm imazapyr treatment, respectively.

It seems that washing reduced the concentration of imazapyr in the solution, so less phytotoxicity was experienced by the rice root. It indicates that imazapyr can be leached away by the flowing water. On the other hand liming $\left(0.1 \% \mathrm{CaCO}_{3}\right)$ increased the phytotoxicity to the rice plant as shown in Table $2 \mathrm{~b}$.

The soil also contributed differential response to the rice root elongation. The availability of imazapyr seems greater under the sandy soil of Laladon (Table $2 \mathrm{c}$ ).

The results of this experiment may explain the different results of imazapyr on crop growth, when imazapyr is applied during or at the end of the dry season. The crop introduced in the following wet season may suffer from imazapyr phytotoxicity. However, when imazapyr is applied in the wet season, crops established one month later will escape imazapyr injury because imazapyr molecules would have been leached by the rainfall. Liming will further speed up leaching if carried out long enough before crops are planted.

\section{REFERENCES}

ARNOLD, P.W. 1981. Surface electrolyte interaction. In D.J. Greenland and M.B. Hayes, eds. The Chemistry of Soil Constituents, John Wiley \& Sons, New York: 355-404.

STOUGAARD, R.N., P.J. SHEA and A.R. MARTIN. 1990. Effect of soil type and pH on adsorption, mobility and efficacy of imozaquin and imazethapyr, Weed Sci, 38: 67-73.

TJTROSEMITO, S. and D. SUWINARNO. 1988. The performance of soybean (C.V. Americana) established by zero tillage technique in Imperata field controlled by herbicides. BIOTROPIA (2): 12- 17.

, PURWANTO. 1991. The performance of upland rice established by zero tillage technique on Imperata field. BIOTROPIA (5): 10- 14.

WEHTJE, G., R. DICKENS, J.W. WILCUT and B.F. HAJEK. 1987. Sorption and mobility of sulfometuron and imazapyr in five Alabama soils. Weed Sci. 35: 858-864. 